\title{
The Role of Law and the Rule of Law in China's Quest to Build an Ecological Civilization
}

\author{
Paul A. BARRESI \\ Professor of Political Science and Environmental Law, School of Arts and \\ Sciences, Southern New Hampshire University; Adjunct Professor of Law, \\ Sun Yat-sen University School of Law \\ p.barresi@snhu.edu
}

\begin{abstract}
Decades of rapid industrialization have caused a dramatic decline in environmental quality in the People's Republic of China, which has prompted Chinese officials to call for redirecting China's modernization efforts toward the construction of an 'ecological civilization' (shengtai wenming 生态文明). The many environmental laws that China has enacted since 1979, which borrow heavily from Western precedents, are a vital part of this effort. Unfortunately, these laws have been plagued by both compliance and enforcement problems. Cultural factors are largely to blame. The many Western-style features of China's environmental laws depend for their effectiveness on the cultural dimensions of a strong rule of law, which are in tension with essential elements of China's ancient legal tradition. China's environmental laws would be more effective allies in its quest to build an ecological civilization if they were aligned more closely with that tradition in at least four ways.
\end{abstract}

\section{Keywords}

Confucianism - ecological civilization - environmental law - legal tradition - legal culture - rule of law 
Decades of rapid industrialization have produced a dramatic decline in environmental quality in the People's Republic of China ('PRC'). ${ }^{1}$ By one official PRC estimate, the economic cost of environmental degradation from pollution and other sources is about ten percent of China's Gross Domestic Product ('GDP'), which roughly equals even the most impressive of China's recent annual GDP growth rates. ${ }^{2}$ This environmental crisis has provoked widespread social unrest, including violence against government officials. ${ }^{3}$

China's leaders are well aware that the nation is hurtling toward the edge of an ecological and social abyss. Since enacting its first environmental statute of national application ( falü 法律) — the Environmental Protection Law ${ }^{4}$-on a trial basis in 1979, China has followed the West's lead by adopting a heavily law-based strategy for mitigating the negative environmental impacts of industrialization. The resulting array of environmental statutes generally conforms to the substantive taxonomy established in the West. ${ }^{5}$ These statutes

1 See generally e.g. Elizabeth C ECONOMY, The River Runs Black: The Environmental Challenge to China's Future (2d edn, Cornell UP 2010).

2 Cf. Kathleen E MCLAUGHLIN, 'General Policy: China Environmental Assessment Estimates \$20o Billion Annual Damage from Pollution' (2006) 29 Int'l Env't Rep 438, with World Bank (GDP Growth (annual \%)) <http://data.worldbank.org/indicator/NY.GDP.MKTP.KD.ZG> accessed 8 September 2012.

3 See e.g. ECONOMY (n 1) 89-91; Reuters, 'Pollution Fuels Protests and Riots, Says Environmental Boss' The Standard (Hong Kong, 21 April 2006).

4 Environmental Protection Law of the People's Republic of China (for Trial Implementation) (effectiveSept13,1979) < www.asianlii.org/cn/legis/cen/laws/eplotproc564/ >. This trialversion was superseded by a permanent version in 1989 , which in turn was superseded by an amended permanent version in 2014, which took effect on January 1, 2015. Compare Environmental Protection Law of the People's Republic of China (effective Dec 26, 1989) <www.ecolex.org> (Legislation ID number: LEX-FAOC003551) (hereinafter PRC Environmental Protection Law), with Environmental Protection Law of the People's Republic of China (effective Jan 1, 2015) <www.chinadialogue.net/Environmental-Protection-Law-2014-eversion.pdf> (hereinafter PRC Amended Environmental Protection Law).

5 See Law of the People's Republic of China on the Prevention and Control of Environmental Noise Pollution (effective March 1, 1997) <www.asianlii.org/cn/legis/cen/laws/lotprocotpacoenp931/> (hereinafter PRC Noise Pollution Law); Marine Environmental Protection Law of the People's Republic of China (effective April 1, 2000) <www.asianlii.org/cn/legis/cen/ laws/meplotproc607/> (hereinafter PRC Marine Environmental Protection Law); Law of the People's Republic of China on the Prevention and Control of Atmospheric Pollution (effective Sept 1, 2000) <www.asianlii.org/cn/legis/cen/laws/lotprocotpacoap841/> (hereinafter PRC Atmospheric Pollution Law); Law of the People's Republic of China on Evaluation of Environmental Effects (effective Sept 1, 2003) <www.asianlii.org/cn/legis/cen/laws/ eoeel368/> (hereinafter PRC Environmental Effects Evaluation Law); Law of the People's Republic of China on the Prevention and Control of Environmental Pollution by Solid Wastes 
also incorporate a host of Western-style policy design principles and policy implementation strategies. From the ambient environmental quality and performance standards at the centre of China's air and water pollution statutes to the two-pronged method for identifying hazardous wastes embraced by its solid waste law, China's environmental statutes are brimming with features pioneered in the United States and Western Europe. ${ }^{6}$

From its inception, China's environmental laws have been plagued by both compliance and enforcement problems. Regulated parties routinely ignore or evade the law, often with the help of local officials. ${ }^{7}$ The problem is partly institutional. By statute, China's environmental laws are enforced by the local Environmental Protection Bureaus ('EPBs') that reside within each of the many nested administrative units into which the PRC Constitution divides the State. ${ }^{8}$ These EPBs derive most of their funding and other resources from the local governments of which they are a part, which tends to make

(effective April 1, 2005) <www.asianlii.org/cn/legis/cen/laws/lotprocotpacoepbsw1034/> (hereinafter PRC Solid Wastes Law); Law of the People's Republic of China on the Prevention and Control of Water Pollution (effective June 1, 2008) <www.ecolex.org> (Legislation ID number: LEX-FAOC 023549) (hereinafter PRC Water Pollution Law).

6 Cf. e.g. PRC Marine Environmental Protection Law (n 5) art 9, paras 1-2, art 10, and PRC Atmospheric Pollution Law (n 5) art 6, art 7, paras 1-2, and PRC Solid Wastes Law (n 5 ) art 88, s 4, and PRC Water Pollution Law (n 5 ) arts 11-12, art 13, paras 1-2, with e.g. Clean Air Act, Pub L 91-604, ss 109, 111, 84 Stat 1676, 1679-80, 1683-84 (1970) (codified as amended at 42 USC ss 7409, 7411), and Federal Water Pollution Control Act, Pub L 92-500, ss 301(a), (b) (2)(A)(i), 303(a)-(c), (g)-(h), 86 Stat 816, 844-45, 846-48, 850 (1972) (codified as amended at 33 USC ss 1311(a), (b)(2)(A)(i), $1313(\mathrm{a})-(\mathrm{c}),(\mathrm{g})-(\mathrm{h}))$, and Council Directive 91/689/EEC of 12 December 1991 on hazardous waste [1991] OJ L377/20, art 1(4), annexes I-III, repealed by Council Directive 2008/98/EC of 19 November 2008 on waste and repealing certain Directives [2008] oJ L312/3, and Council Directive 2000/6o/EC establishing a framework for Community action in the field of water policy [2000] OJ L327/1, arts 10(2)(b), 16(1), (7)-(8) (as amended), and Council Directive 2001/80/EC of 23 October 2001 on the limitation of emissions of certain pollutants into the air from large combustion plants [2001] OJ L309/1, annexes III-VII, and Council Directive 2008/50/EC of 21 May 2008 on ambient air quality and cleaner air for Europe [2008] oJ L152/1, annexes VII, XI, XIV, and Council Directive 2008/98/ EC of 19 November 2008 on waste and repealing certain Directives [2008] oJ L312/3, art 3(2), annex III, and 40 CFR Ss 261.3(a)(2)(i)-(ii), 261.20(a), 261.21-.24, 261.31-.33 (2016).

7 See e.g., ECONOMY (n 1$) 5-6,7,75,115$.

8 SONG Ying, 'The Chinese Environmental Lawmaking Framework' (2002) 1 Chinese J Int'l L 225, 231. Cf. e.g. Constitution of the People's Republic of China arts 30, 105, 115 (1982, as amended 1988, 1993, 1999 \& 2004), translated at <http://english.people.com.cn/constitution/ constitution.html> (hereinafter PRC CONST, with the date of enactment of provisions currently in force noted parenthetically). 
them much more responsive to the latter than to their official superiors in the Ministry of Environmental Protection in Beijing. ${ }^{9}$ Powerful political incentives in turn have led local government officials to prioritize economic development over nearly every other policy goal, even when environmental laws require otherwise. ${ }^{10}$ Although the newest version of China's Environmental Protection Law tries to address this problem by establishing an 'environmental protection target accountability and performance evaluation system' for local governments and officials, ${ }^{11}$ the effectiveness of this new system remains to be seen.

Beneath this institutional obstacle to the effectiveness of China's environmental laws, however, lies a deeper, cultural one. The Western-style features of those laws depend for their effectiveness on a strong rule of law, a phenomenon of Western origin with ancient Greek roots that has become a hallmark of modernity. ${ }^{12}$ Ever since the British jurist A. V. Dicey $\left(1835^{-1922}\right)$ offered the first modern definition of the rule of law in $1885,{ }^{13}$ Western legal scholars have defined the concept in terms of its intended goals. ${ }^{14}$ These goals are distinct but intertwined, and often are in conflict. ${ }^{15}$ Most of them have essential cultural dimensions implied by equally essential elements of Western legal traditions. ${ }^{16}$

By 'legal tradition,' I mean 'a set of deeply rooted, historically conditioned attitudes about the nature of law, about the role of law in the society and the polity, about the proper organization and operation of a legal system, and about the way law is or should be made, applied, studied, perfected, and taught.' ${ }^{17}$ A society's legal tradition comprises the core, if not the entirety, of its

9 See ECONOMY (n 1$) 113$.

10 See Michael STANDAERT, 'Enforcement: Enforcement of Environmental Laws in China Hindered by Local Officials' Focus on Growth' (2011) 34 Int'l Env't Rep 255.

11 See PRC Amended Environmental Protection Law (n 4) art 26.

12 Cf. Randall PEERENBOOM, China's Long March Toward Rule of Law (Cambridge UP 2002), 224; Rachel Kleinfeld BELTON 'Competing Definitions of the Rule of Law' (2005) Carnegie Endowment for Int'l Peace Rule of Law Series No 55, 7, 8, $9<\mathrm{http}$ ://carnegieen dowment.org/files/CP55.Belton.FINAL.pdf> accessed ${ }_{17}$ December 2016. Cf. A V DICEY, Lectures Introductory to the Study of the Law of the Constitution (Macmillan 1885) 215-16.

14 See generally BELTON ( $\mathrm{n} 12) 5-6,7-8,9,14,15,29 \mathrm{n} 10$.

15 See e.g. ibid. $15,24-25$.

16 Cf. ibid. 21-22, $30 \mathrm{n} 24$.

17 John Henry MERRYMAN \& Rogelio PÉREZ-PERDOMO, The Civil Law Tradition (3rd edn, Stanford UP 2007) 2. 
legal culture. ${ }^{18}$ A society's legal system is the set of institutions through which that society's legal culture and tradition are expressed. ${ }^{19}$

Two of the world's great legal traditions - the civil law and common law traditions-emerged in the West in the eleventh century CE, although the former was inspired by the law of the ancient Roman republic. ${ }^{20}$ The Chinese legal tradition is up to several centuries older than even the Roman civil law, and has had as much impact on the legal systems of East Asia as the civil law and common law traditions have had on legal systems elsewhere. ${ }^{21}$ The culture clash between the ancient Confucian essence of the Chinese legal tradition and essential cultural dimensions of the modern rule-of-law concept plays a crucial role in undermining the effectiveness of the Western-style features of the PRC's environmental laws. ${ }^{22}$

The persistence of China's environmental crisis has prompted officials at the highest levels of the Central Government and the Communist Party of China ('CPC') to call for redirecting China's modernization efforts toward the goal of building an 'ecological civilization' (shengtai wenming 生态文明), ${ }^{23}$

18 Cf. ibid. By culture, I mean the set of descriptive and prescriptive beliefs and associated behaviors that together define a distinct way of life for the members of a given social group in a given domain of experience, and are transmitted socially between generations. This definition falls squarely within the scope of the ordinary usage of the term. See John GERRING \& Paul A. BARRESI, 'Culture: Joining Minimal Definitions and Ideal-Types' in David COLLIER \& John GERRING (eds), Concepts and Method in Social Science: The Tradition of Giovanni Sartori (Routledge 2009) 241.

19 Cf. MERRYMAN \& PÉREZ-PERDOMO (n 17$) 2$.

20 Ibid. 2-4, 8-10.

21 See John W. HEAD \& Yanping WANG, Law Codes in Dynastic China (Carolina Academic Press 2005) 3-4.

22 Cf. MERRYMAN \& PÉREZ-PERDOMO (n 17) 4. For an earlier exploration of related points, see Paul A BARRESI, 'The Chinese Legal Tradition as a Cultural Constraint on the Westernization of Chinese Environmental Law and Policy: Toward a Chinese Environmental Law and Policy Regime with More Chinese Characteristics' (2013) 30 Pace Envtl L Rev 1156 .

23 See e.g. HU Jintao, 'Hold High the Great Banner of Socialism with Chinese Characteristics and Strive for New Victories in Building a Moderately Prosperous Society in All Respects: Report to the Seventeenth National Congress of the Communist Party of China on Oct. 15, 2007' (2007) s IV, para 7 <www.china.org.cn/english/congress/229611.htm> accessed 20 October 2012; WEN Jiabao, State Council Premier, PRC, 'Seeking Innovative Ideas, Taking Pragmatic Actions and Adhering to the Road of Sustainable Development with Chinese Characteristics - Speech at a High-Level Roundtable of the United Nations Conference on Sustainable Development (Rio de Janeiro, Brazil, June 20, 2012)', translated 
the Chinese characters for which also have been translated as 'conservation culture' or 'ecological progress' in official documents and the Chinese press. ${ }^{24}$ The ecological civilization concept was the brainchild of Professor Ye Qianji, an agricultural economist at China's Southwest Agricultural (now Southwest) University, who proposed it in $1986 .{ }^{25}$ Since 2007 , it has been embraced publicly at the highest levels of the Chinese State and the $\mathrm{CPC}^{26}{ }^{26}$ has been affirmed in the CPC constitution, ${ }^{27}$ and has been enshrined as a goal in the newest version of China's Environmental Protection Law. ${ }^{28}$

In its official incarnation, the ecological civilization concept seeks to transcend the Western model of industrial modernization by —as CPC General Secretary and PRC President Hu Jintao put it-basically forming an energyand resource-efficient and environment-friendly structure of industries, pattern of growth and mode of consumption.29 Notwithstanding this postmodern gloss, however, the concept also has purported since its earliest years

in China News \& Rep (Beijing, 15 July 2012) 4 <http://english.cri.cn/mmsource/images/ 2012/07/13/eng120713.pdf $>$ accessed 20 October 2012; ZHOU Shengxian, Environmental Protection Minister, PRC, 'Building Ecological Civilization and Sustainable DevelopmentAddress at the Eco Forum Global 2012' (27 July 2012), translated at <http://english.mep. gov.cn/Ministers/Speeches/201208/t20120807_234449.htm> accessed 14 October 2012. 'CPC Advocates Building "Beautiful" China' Xinhua (Beijing, 8 November 2012) <http:// news.xinhuanet.com/english/special/18cpcnc/2012-11/o8/c_131959465.htm > accessed 15 January 2013. Compare 'Ecological Civilization' (Op-Ed) China Daily (Beijing, 24 October 2007) 10 <www.chinadaily.com.cn/opinion/2007-10/24/content_6201964.htm> accessed 20 October 2012, with "Hu Jintao Advocates "Conservation Culture" for First Time in Keynote Political Document' Xinhua (Beijing, 15 October 2007) <http://news.xinhuanet.com/english/2007-10/15/content_6883510.htm> accessed 10 October 2011. See WANG Lianyong, 'A Seminal Book Written by Professor Ye Discussing the Ecological Civilization Building for 21st Century' (Chongqing, 24 June 2016) 2 (unpublished manuscript).

26 See 'Hu Jintao Advocates "Conservation Culture"' (n 24). Cf Opinions of the CPC Central Committee \& State Council on Further Promoting the Development of Ecological Civilization (April 25, 2015), translated at Deutsche Gesellschaft für Internationale Zusammenarbeit (Sino-German Environmental Partnership) <http://environmentalpartnership.org/wp-content/uploads/download-folder/Eco-Guidelines_rev_Eng.pdf> accessed 22 December 2016 (hereinafter Opinions on Ecological Civilization).

27 See Constitution of the Communist Party of China (revised and adopted at the 18th Nat'l Cong of the Communist Party of China, Nov 14, 2012), at General Program paras 9, 18, translated at China.org.cn (The 18th National Congress of the Communist Party of China $(C P C))<$ www.china.org.cn/china/18th_cpc_congress/2012-11/16/content_27138030.htm>.

28 See Amended PRC Environmental Protection Law (n 4) pmbl, art 1. HU Jintao (n 23) s IV, para 7. 
to look to China's ancient traditions, including Confucianism, for the wisdom necessary to achieve those goals. ${ }^{30}$ The ecological civilization concept thus shares with China's legal tradition insights drawn from the same ancient and enduring philosophical source. Using the United States as a point of comparison, this article argues that China's environmental laws would be more effective allies in its quest to build an ecological civilization if they were aligned more closely with China's own legal tradition, and thus were to depend less for their effectiveness on the cultural dimensions of the strong rule of law that prevails in the Western countries from which many of the essential features of those laws were derived.

\section{Implications of Rule-of-law Goals for the Effectiveness of the Western-Style Features of Environmental Laws in China and the United States}

As he travelled the length and breadth of the United States for nine months in 1831, the French nobleman Alexis de Tocqueville was struck by the role of the law as a principal touchstone of American culture. ${ }^{31}$ Nearly 200 years later, his observations remain among the most insightful. 'Scarcely any political question arises in the United States,' de Tocqueville remarked,

that is not resolved, sooner or later, into a judicial question. Hence all parties are obliged to borrow, in their daily controversies, the ideas, and even the language, peculiar to judicial proceedings. As most public men are or have been legal practitioners, they introduce the customs and technicalities of their profession into the management of public affairs. The jury extends this habit to all classes. The language of the law thus becomes, in some measure a vulgar tongue; the spirit of the law, which is produced in the schools and courts of justice, gradually penetrates beyond their walls into the bosom of society, where it descends to the lowest classes,

30 See e.g. YE Qianji, Eco-Farming: Toward a Post-Modern Agriculture (Chongqing 1988) 332-35 (translated in WANG Lianyong (n 25) 15-16); PAN Yue, 'Evolution of an Ecological Civilization' (2006) 49 [November 9] Beijing Rev 18, 18-19; PAN Yue, 'Looking Forward to an Ecological Civilization' China Today (Beijing, November 2008) 29, 30.

31 See Alexis de TOCQUEVILLE, Democracy in America, vol 1 (original work 1835, Henry REEVE trs, 1835, Francis BOWEN retrs, 1862, Phillips BRADLEY ed, Vintage Books 1945) 290 (hereinafter DE TOCQUEVILLE I). 
so that at last the whole people contract the habits and the tastes of the judicial magistrate. ${ }^{32}$

Law's pride of place in Americans' cultural conceptions of themselves and their polity is largely responsible for the unusually high degree to which the United States has achieved most rule-of-law goals. This phenomenon in turn plays a crucial role in ensuring the effectiveness of us environmental laws. The role of the law in China's political and popular cultures could not be more different. This difference has crucial implications for all five of the goals that Western legal scholars generally consider the rule of law to be intended to achieve, and thus for the effectiveness of the Western-style policy design principles and policy implementation strategies at the heart of China's environmental laws.

\subsection{Law as a Means of Binding the State}

The original goal of the rule of law concept was a State bound by law, both procedurally and substantively. ${ }^{33}$ Achieving this goal is among the most crucial prerequisites for the effectiveness of the Western-style features of any society's environmental laws because it ensures that the administrative authorities will implement the laws as the legislative authorities intended. Americans have shared a belief since the birth of the Republic that the State is and should be bound by law, as expressed in the commonplace observation that Americanstyle government is 'a government of laws, not of men.'34 One of the most obvious manifestations of this belief in the context of us environmental law is the frequency with which environmental agencies in the executive branch of the Federal Government revisit their actions - and, in some cases, inactionafter being ordered to do so by a court on the ground that the agency failed to conform to the substantive or procedural requirements established by the legislature. ${ }^{35}$

32 Ibid

33 Cf. BELTON (n 12) 8-9. Strictly speaking, this goal merely requires the State to execute its decisions in accordance with the law, which it may change only through established legislative procedures. See ibid. 9. Given that the law may impose a broad array of procedural and substantive requirements on the executive functions of the State, however, this ostensibly procedural goal at least implies the possibility of substantive legal constraints on state power.

34 See e.g. MASS CONST art Xxx; Marbury v Madison, 5 Us (1 Cranch) 137, 163 (1803); Truax v Corrigan, 257 US 312, 331 (1921).

35 Cf. e.g. Lettie M WENNER, The Environmental Decade in Court (Indiana UP 1982) 65-67, $68-69,69-70,73-74$. 
The aftermath of the decision of the us Supreme Court in Massachusetts v. $E P A^{36}$ offers an especially consequential illustration of this rule-of-law phenomenon. The sequence of events that led to the Court's decision began with a rulemaking petition filed with EPA in 1999 by several environmental interest groups, in which they asked EPA to establish various greenhouse gas ('GHG') emission standards that would apply to new motor vehicles under the federal Clean Air Act. ${ }^{37}$ EPA denied the petition in 2003, partly on the basis of the agency's own conclusion that the statute does not authorize EPA to regulate GHG emissions. ${ }^{38}$ The environmental groups and certain State governments then sued EPA in federal court. ${ }^{39}$ On appeal, the Supreme Court held that the Clean Air Act's definition of 'air pollutant' is broad enough to authorize EPA to regulate $\mathrm{GHGS},{ }^{40}$ and ordered $\mathrm{EPA}$ either to determine whether or not GHGS meet the 'endangerment' criterion that would trigger the statutory requirement for promulgating emissions standards, or to offer reasons grounded in the statute for its inability to make such a determination..$^{41} \mathrm{EPA}$ subsequently determined that GHGs do meet the 'endangerment' criterion. ${ }^{42}$ This finding in turn triggered several other provisions of the Clean Air Act that require EPA to promulgate other types of regulations, which it soon started doing, albeit not without facing further lawsuits. ${ }^{43}$

The idea that the State is bound by and should be bound by the law, as illustrated by the aftermath of Massachusetts v. EPA, is foreign to the Chinese legal tradition. Accordingly, for more than 2000 years the Chinese emperors were considered to be above the law ( $f a$ 法), answering only to Heaven (tian 天). ${ }^{44}$

$36 \quad 549$ US 497 (2007).

37 See James KENNEDY, 'Climate Change: Groups Urge EPA to Limit Automotive $\mathrm{CO}_{2}$, Vow Suit Unless Tailpipe Gases Regulated' (1999) 30 Env't Rep 1127.

38 See Pamela NAJOR, 'Climate Change: E PA Says It Does Not Have Authority to Regulate Carbon Dioxide from Vehicles' (2003) 34 Env't Rep 1925.

See Pamela NAJOR, 'Climate Change: States, Cities, Advocacy Groups File Lawsuit Saying EPA Has Authority to Regulate Gases' (2003) 34 Env't Rep 2381.

$40 \quad 549$ Us at 532 .

41 See ibid. $53^{2-35}$.

42 Endangerment and Cause or Contribute Findings for Greenhouse Gases Under Section 202(a) of the Clean Air Act, 74 Fed Reg 66,496 (Dec 15, 2009).

43 See e.g. R Morgan GILHulY \& Christopher JENSEN, 'Congress Missing in Action as Courts Back Clean Air Act Curbs on Emissions' (2012) 43 Env't Rep 2154; Andrew CHILDERS, 'Climate Regulation: EPA Makes Last Defense of Power Plan Carbon Rule' (2016) 47 Env't Rep 4325.

44 See Stanley B LUBMAN, Bird in a Cage: Legal Reform in China After Mao (Stanford uP 1999) 15-16, 17; PEERENBOOM (n 8) 41. 
The law was nearly as impotent a constraint on state power during the brief life of the nominal republic that succeeded the Empire. Within three years of the inauguration of the Republic's first permanent President, Yuan Shikai, ${ }^{45}$ in October 1913, the adoption of a new constitutional compact and the amendment of the Republic's election law had helped to make him, as Western scholars have observed, not only 'a minor Mussolini in a period when no Mussolini had yet emerged for precedent,' but an 'emperor in all but name. ${ }^{46}$ The law was only slightly more effective in constraining the power of Yuan's final successor on the mainland, Chiang Kai-shek, or the power of his political party, the Guomindang. The Republic's first constitution, finally adopted in 1947, formally confirmed the expansive powers that Chiang had wielded for nearly two decades as China's supreme leader. ${ }^{47}$ Supplementary provisions promulgated by Chiang's government ten days before his inauguration as President, which were supposed to remain in effect only for the duration of the civil war that the Guomindang considered to be merely a Communist rebellion, dealt a body blow to the normal institutional constraints on presidential power. ${ }^{48}$ These nominally 'temporary' provisions remained in effect for more than forty years, surviving by more than fifteen years even Chiang himself, who died in office on the island of Taiwan. ${ }^{49}$

Mao Zedong proclaimed the founding of the PRC in October 1949, even before Chiang's flight from the mainland. ${ }^{50}$ This change of leadership did nothing to make the law more binding on the Chinese State, however. Mao

45 See generally Jerome CH'ÊN, Yuan Shih-k'ai (George Allen \& Unwin 1961) 46-62, 76-100, 110-13, 172.

46 John K FAIRBANK, Edwin O REISCHAUER \& Albert M CRAIG, East Asia: The Modern Transformation (Houghton Mifflin 1965) 646; Lyon SHARMAN, Sun Yat-sen: His Life and Its Meaning (John Day 1934) 203. See also Chên (n 45) 201-02; FAIRBANK, REISCHAUER \& CRAIG (n 46) 641, 646; PAN Wei-tung, The Chinese Constitution: A Study of Forty Years of Constitution-making in China (PAN Wei-tung 1945) 28-29.

47 See Constitution of the Republic of China arts $35^{-44}$ (1947, as modified by temporary provisions 1948-91, and amended 1991 \& 1992), translated in HUNGDAH Chiu, 'Constitutional Development and Reform in the Republic of China on Taiwan (with Documents)' (1993) University of Maryland School of Law Occasional Papers/Reprints Series in Contemporary Asian Studies No 115, 42 <http://digitalcommons.law.umaryland. edu/mscas/volig93/iss2/1/> accessed 23 August 2012.

48 See Temporary [Constitutional] Provisions Effective During the Period of Communist Rebellion arts 1-6, 8, 10 (1948, as amended 196o, 1966 \& 1972) (abrogated 1991), translated in HUNGDAH Chiu (n 47) 50.

49 HUNGDAH Chiu (n 47) 31. See generally Jonathan FENBY, Chiang Kai-shek: China's Generalissimo and the Nation He Lost (Carroll \& Graf 2004) 497-500.

5o See FAIRBANK, REISCHAUER \& CRAIG (n 46) 862. 
himself remained at least as unconstrained by it as his imperial and nominally republican predecessors had been. After briefly tolerating efforts to construct a socialist legal system in the early $1950 \mathrm{~s}^{51}{ }^{51}$ Mao openly condemned even Sovietstyle legal institutions as unacceptable constraints on class struggle..$^{52}$ Soon he began dismantling China's budding socialist legal system with a vengeance. ${ }^{53}$ By the mid-196os, during the Cultural Revolution, the Central Government essentially had adopted lawlessness as its official policy. ${ }^{54}$

At the Third Plenum of the Eleventh Central Committee of the CPC in 1978, Deng Xiaoping - who was then well on his way to consolidating his power as the PRC's new supreme leader ${ }^{5}$ — called for China to strengthen its 'socialist legal system. ${ }^{56}$ The Plenum's endorsement of Deng's call marks the start of the modern era of China's legal history. ${ }^{57}$ Deng's principal aim was to avoid a reprise of the essentially official lawlessness that he blamed for causing mass suffering during the Cultural Revolution and for damaging the CPC in the eyes of the people. ${ }^{8}$ In accordance with this goal, China's newest constitution, adopted soon after Deng consolidated his power, ${ }^{59}$ asserts that "[a]ll state organs ... and all enterprises ... must abide by the Constitution and the law. ${ }^{\prime 60}$ For the most part, however, senior PRC leaders and the CPC have remained wholly or

51 Cf. YU Xingzhong, Comment, 'Legal Pragmatism in the People's Republic of China' (1989) 3 J Chinese L 29, 36-37; Perry KELLER, 'Sources of Order in Chinese Law' (1994) 42 Am J Comp L 711, 720 .

52 See Carlos Wing-Hung LO, 'Socialist Legal Theory in Deng Xiaoping's China' (1997) 11 Colum J Asian L 469, 473.

53 See PEERENBOOM (n 12) 44-45; Keller (n 51 ) 723 .

54 See PEERENBOOM (n 12) 45; SHAO-CHUAN Leng, 'The Role of Law in the People's Republic of China as Reflecting Mao Tse-tung's Influence' (1977) 68 J Crim L \& Criminology 356, 359-6o. Cf 'In Praise of Lawlessness' People's Daily (Beijing, 31 January 1967) translated in us Consulate General, Hong Kong, Survey of China Mainland Press (Hong Kong, 14 February 1967).

55 Cf. Henry KISSINGER, On China (Penguin Press 2011) 329-39.

56 See DENG Xiaoping, 'Emancipate the Mind, Seek Truth from Facts and Unite as One in Looking to the Future (December 13, 1978)' in Selected Works of Deng Xiaoping (1975-1982) (Foreign Languages Press 1984) 157-58.

57 See Daniel C K CHOW, The Legal System of the People's Republic of China in a Nutshell (West Group 2003) 56-57.

58 See DENG Xiaoping, 'On the Reform of the System of Party and State Leadership (August 18, 1980)' in Selected Works of Deng Xiaoping (1975-1982) (Bureau for the Compilation and Translation of Works of Marx, Engels, Lenin and Stalin Under the Central Committee of the Communist Party of China 1984) 309, 315-16.

Cf. KISSINGER (n 55) 329-39.

6o PRC CONST (n 8) art 5 (1982). 
partly above the law. ${ }^{61}$ The anti-corruption drive against senior government and party officials that Xi Jinping initiated soon after assuming the posts of CPC General Secretary and PRC President in 2012 and 2013, respectively, merely highlights this point. ${ }^{62}$ Similarly, the frequency with which local officials have succeeded in thwarting the efforts of local EPBs to enforce China's environmental laws, and with which state-owned enterprises have succeeded in evading the laws' requirements, underscores the extent to which the goal of a State bound by law remains aspirational in China. This merely aspirational quality is inconsistent with one of the most crucial prerequisites for the effectiveness of the Western-style features of China's environmental laws because it reduces the likelihood that the administrative authorities will implement them as the legislative authorities intended.

\subsection{Law as a Means of Ensuring Equal Treatment}

The second goal of the rule of law is the equality of all persons before the law. ${ }^{63}$ Achieving this goal is among the most crucial prerequisites for the effectiveness of the Western-style features of any society's environmental laws because it ensures that the burden of compliance will be shared by all parties responsible for the challenges that those laws are intended to meet. In the United States, de Tocqueville was struck by the extent to which the inhabitants seemed oblivious to the possibility that the law could be applied unequally, as if equality before the law were the natural condition of humankind. ${ }^{64}$ The American legal system has institutionalized this cultural perspective to a very high degree. As the us Supreme Court emphasized in Truax v. Corrigan, ${ }^{65}$ '[o] ur whole system of law is predicated on the general fundamental principle of equality of application of the law.'66

One of the most obvious manifestations of the equality of all persons before the law in the us environmental law context is the extent to which the laws impose the same substantive and procedural requirements on all regulated parties within broad categories defined by the intrinsic characteristics of their

\footnotetext{
61 See PEERENBOOM (n 12) 132, 214-15, 217, 419.

62 See e.g. Andrew Jacobs, 'Elite in China Face Austerity Under Xi's Rule' The New York Times (New York, 27 March 2013) < www.nytimes.com/2013/03/28/world/asia/xi-jinpingimposes-austerity-measures-on-chinas-elite.html> accessed 26 August 2016.

63 Cf. BELTON (n 12) 9-10.

64 See Alexis DE TOCQUEVILLE, Democracy in America, vol 2 (original work 1840, Henry REEVE trs, 1840, Francis BOWEN retrs, 1862, Phillips BRADLEY ed, Vintage Books 1945) 307.

65257 US 312, 331 (1921).

66 Ibid. 331 .
} 
members. The Clean Air Act, ${ }^{67}$ for example, requires new stationary sources of certain types of air pollutants to meet performance standards that reflect certain statutorily defined criteria for the category of sources in question. ${ }^{68} \mathrm{EPA}$ 's implementing regulations express these standards as concentration-like numerical limits that apply uniformly to emissions from new stationary sources in categorically defined industrial sectors, such as fossil-fuel-fired steam generators other than electric utilities, with some variation in the standards depending on certain differences in the characteristics of the particular facilities that fall into the general sectoral categories. ${ }^{69}$

On their face, China's environmental laws generally purport to work in the same way. The state standards for the discharge of water pollutants established by regulation under China's Law on the Prevention and Control of Water Pollution, ${ }^{70}$ for example, are expressed as numerical concentrations that purport to apply uniformly to facilities in categorically defined industrial sectors, such as rare earth mining. ${ }^{71}$ Therein lies the problem, however, because the principle of equality of all persons before the law of which the nearly universal applicability of similar requirements in the West is an expression is foreign to the Chinese legal tradition. ${ }^{72}$ The laws of the Empire, for example, treated different persons differently depending on their absolute or relative status within the Confucian social hierarchy on which Chinese society was based at the time. ${ }^{73}$ In the socialist legal system that briefly began to emerge under Mao Zedong, class status replaced Confucian social rank as the relevant criterion, but the tradition of applying the law unequally survived. ${ }^{74}$ Deng Xiaoping

67 Pub L 92-50o, 86 Stat 816 (1972) (codified as amended at 33 USC ss 1251-1387).

68 See Clean Air Act, s 111(a) (1), (b)(1), (e), 42 USC s 7411(a)(1), (b)(1), (e) (2012).

69 See e.g. Standards of Performance for Fossil-Fuel-Fired Steam Generators, 40 CFR pt 6o, sbpt D (2016).

$70 \quad$ PRC Water Pollution Law ( $\left.\mathrm{n}_{5}\right)$ art 13.

71 See e.g. Michael STANDAERT, 'Mining: China Prepares to Issue New Standards to Clean Up Rare Earths Mining Sector' (2011) 34 Int'l Env't Rep 94.

72 Cf. e.g. Derk BODDE \& Clarence MORRIS, Law in Imperial China (University of Pennsylvania Press 1967) 21, 29.

73 See ibid. 29, 30, 33-38, 43; William C JONES, 'Introduction' to William C Jones (trs), with the assistance of Tianquan CHENG \& Yongling JIANG, The Great Qing Code (ouP 1994) $16-17$.

74 See LENG (n 54) 363-65; LO, 'Socialist Legal Theory' (n 52) 473, 473-74 n 14. The extent to which the laws of the nominally republican governments that purported to rule China between the collapse of the Empire in 1911 and the founding of the PRC in 1949 might have claimed to embrace the Western principle of equality before the law is of little importance here because those laws had little practical impact on Chinese society. See Franz 
purported to make equality before the law one of the main goals of his postMao reforms ${ }^{75}$ His principal aim was merely to avoid a repetition of the mass suffering and damage to the CPC's reputation caused during the Cultural Revolution by certain CPC cadres who had enjoyed extra-legal political and economic privileges because of their party status, however, not an embrace of the Western concept of equality before the law per se. ${ }^{76}$ In any case, the belief that laws should be applied in ways that reflect extra-legal factors such as the relationship and circumstances of the parties and widely-shared conceptions of justice is pervasive in China. ${ }^{77}$ This belief is inconsistent with one of the most crucial prerequisites for the effectiveness of the Western-style features of China's environmental laws because it reduces the likelihood that the burden of compliance will be shared by all parties responsible for the challenges that those laws are intended to meet.

\subsection{Law as a Means of Maintaining Social Order}

The third goal of the rule of law is the maintenance of social order in the sense of protecting citizens from each other, whether civilly or criminally. ${ }^{78}$ Achieving this goal is a crucial prerequisite for the effectiveness of the Western-style features of a society's environmental laws-at least in societies with market-based economies-because it speaks directly to the principal social challenge that those features are intended to meet. One of the hallmarks of such societies is the pervasive private ownership of the means of producing wealth. One of the principal purposes of environmental laws in that context is the protection of citizens from the negative environmental externalities of the economic activities of other citizens as owners of the means of production. ${ }^{79}$ One of the most visible manifestations of the high degree to which the United States has achieved this rule-of-law goal is the extent to which Americans rely on the law as a means of resolving their social disputes, ${ }^{80}$ including in envi-

MICHAEL, 'The Role of Law in Traditional, Nationalist and Communist China' [1962] China Q 133-34; Keller (n 51) 718-19.

75 See e.g. Carlos W H LO, 'Deng Xiaoping's Ideas on Law: China on the Threshold of a Legal Order' (1992) 32 Asian Surv 649, 653-54, 656.

76 See DENG Xiaoping, 'On Reform' (n 58) 302, 309, 315-16.

77 See KELLER (n 51$)$ 714-15.

78 Cf. BELTON (n 12) 10-12.

79 Cf. e.g. Henry J MCGURREN, 'Externalities of a Torrey Canyon Situation: An Impetus for Change in Legislation' (1971) 11 Nat Resources J 349.

80 See e.g. Peter Charles HOFFER, 'Honor and the Roots of American Litigiousness' (1989) 33 Am J Legal Hist 295. 
ronmental contexts. Nearly all federal environmental statutes include 'citizen suit' provisions, which in relevant part authorize private parties to sue other private parties civilly to force them to comply with the statute, its implementing regulations, or related measures. ${ }^{81}$

In accordance with the Chinese legal tradition, law almost never has played more than a subordinate role in maintaining social order in China. It played the dominant role only during the short-lived dynasty that unified China - the Qin (221-206 вСЕ) — during which the use of law to maintain social order was deeply unpopular. ${ }^{82}$ From the Former and Later Han Dynasties (206 BCE $-8 \mathrm{CE}$ and $25^{-220} \mathrm{CE}$, respectively) through the final imperial dynasty—the Qing (1644-1911 CE) —Confucian behavioural norms (li 礼) were much more important than law in protecting citizens from each other. ${ }^{83}$ Although the Guomindang tried to Westernize China's legal system during the nominal republic that followed the Empire, their efforts had little impact on this traditional pattern. ${ }^{84}$ Nor did law assume any greater importance as a means of maintaining social order under CPC rule. The administrative system with which the CPC essentially replaced the Guomindang's legal system in the parts of China that the former controlled even before 1949 mostly remained in place for the first few years after the founding of the PRC. ${ }^{85}$ Although the CPC started to build a formal legal system in the early $1950 \mathrm{0},{ }^{86}$ it was gutted by Mao within a few years, ${ }^{87}$ with any capacity that law might have had for maintaining social order in China vanishing entirely during the essentially official

81 See Toxic Substances Control Act s 20, 15 USC s 2619 (2012); Endangered Species Act of 1973 s 11(g), 16 USC s 1540(g) (2012); Federal Water Pollution Control Act s 505, 33 USC s 1365 (2012); Ocean Dumping Act s 105(g), 33 USC s 1415(g) (2012); Safe Drinking Water Act, 42 USC s 300j-8 (2012); Noise Control Act of 1972 s 12, 42 USC s 4911 (2012); Clean Air Act s 304, 42 USC s 7604 (2012); Resource Conservation and Recovery Act of 1976 s 7002, 42 USC s 7962 (2012); Comprehensive Environmental Response, Compensation and Liability Act of 1980 s 310, 42 USC s 9659 (2012); Emergency Planning and Community Right-to-Know Act of 1986 ss $326(a)(1),(c), 42$ USC ss $11046(a)(1)$, (c) (2012). In practice, the 'citizens' who use these provisions to enforce the requirements of the law against private parties are usually environmental interest groups. See WENNER (n 35) 40, 41 table 6.

82 See HEAD \& WANG (n 21) 63-75.

83 See e.g. Edwin O REISCHAUER \& John K FAIRBANK, East Asia: The Great Tradition (Houghton Mifflin 1960) 30.

84 See MICHAEL (n 74) 133-34; Keller (n 51) 718-19.

85 See KELLER (n 51$) 719$.

86 See YU Xingzhong (n 51) 36; Keller (n 14) 720.

87 See PEERENBOOM (n 12) 44-45; Keller (n 51$) 723$. 
lawlessness of the Cultural Revolution. ${ }^{88}$ Even today, the law remains less important than other means of maintaining social order in China. ${ }^{89}$

In at least one important respect, China's environmental laws are consistent with the subordinate role in maintaining social order that law almost always has played in China. Although most of China's environmental statutes include provisions that authorize private parties to sue or to enter into mediation to enjoin the activities of, or for compensation for environmental damage caused by, other private parties, these statutes do not authorize private parties to forestall any such damage by enforcing the statutory requirements against other private parties before the fact. ${ }^{90}$ Law's consistently subordinate role as a means of maintaining social order in China is inconsistent with a crucial prerequisite for the effectiveness of the Western-style features of China's environmental laws because it undermines those features as a means of protecting citizens from the negative environmental externalities of the economic activities of other citizens as owners of the means of production.

\subsection{Law as a Means of Ensuring Predicable, Efficient Justice}

The fourth goal of the rule of law is predictable and efficient justice, including relatively little delay in the judicial process. ${ }^{91}$ Although this goal is not the most important prerequisite for the effectiveness of the Western-style features of any society's environmental laws, achieving it can contribute to the effectiveness of those features by enhancing their legitimacy in the eyes of the regulated parties, thus encouraging voluntary compliance. In the United States, the judicial resolution of disputes can take years from the filing of a civil complaint or criminal indictment through the exhaustion of a final appeal-almost three and a half years in the GHG case Massachusetts v. EPA, ${ }^{92}$ for example, on top of the nearly four years that it took EPA to deny the environmental interest groups' petition to regulate GHGs in the first place ${ }^{93}$ - but the procedural standardization imposed by the courts' own rules of civil and criminal

88 See PEERENBOOM (n 12) 45; Leng (n 54) 359-6o.

89 See e.g. Tom DOWNEY, 'China's Cyberposse' The New York Times Magazine (New York, 3 March 2010) <www.nytimes.com/2010/03/o7/magazine/o7Human-t.html> accessed 27 May 2017.

90 See e.g. PrC Noise Pollution Law (n 5) art 61; PrC Atmospheric Pollution Law (n 5) art 62; PRC Solid Wastes Law (n 5) art 84; PRC Water Pollution Law (n 5) arts 85-86; PRC Amended Environmental Protection Law (n 4) art 64.

91 Cf. BELTON (n 12) 12-14.

92549 US 497 (2007).

93 See NAJOR, 'Climate Change: EPA Says' (n 38); NAJOR, 'Climate Change: Groups File Lawsuit' (n 39); Andrew S NEAL, 'Mobile Sources: Supreme Court Finds EPA Has Authority to Regulate Greenhouse Gases from Vehicles' (2007) 38 Env't Rep 797. 
procedure make the process both as predictable and as efficient as due process will allow. ${ }^{94}$

Despite frequent complaints about delay, there is little reason to believe that the judicial process in China is more susceptible to it than elsewhere. ${ }^{95}$ Critics also have cited the enforcement of civil judgments in China as problematic, although whether it is more problematic there than elsewhere, including the United States, is debatable. ${ }^{96}$ The fact that Chinese judges are often subject to ex parte appeals for favouritism from the families and friends of litigants is probably much more relevant to the role of law in ensuring predictable and efficient justice. ${ }^{97}$ The same holds true with respect to appeals for special treatment from the parties themselves. The judiciary in Guangdong province has reported, for example, that local litigants sometimes threaten to harm themselves if the judge does not resolve the dispute in their favour. ${ }^{98}$ In a society that has functioned for millennia largely on the basis of guanxi (关系)—roughly, 'personal networks' - and in which public officials have been expected for just as long to temper the performance of their official duties with renqing (人情)—roughly, 'human feelings or empathy' — these appeals are a powerful form of social pressure that encourages judges to bend the law rather than to risk social ostracism. ${ }^{99}$ Judges also often bow to the pressure exerted by the local officials who appoint and remove them and who control judicial budgets to favour local interests in resolving commercial and administrative disputes. ${ }^{100}$ These and other factors render the administration of justice in China much less predictable than otherwise could be the case. ${ }^{101}$ Thus, they do nothing to enhance the legitimacy of the Western-style features of China's environmental

94 Cf. e.g. us Const amends v, Xiv s 1; Fed R Civ P 1; Fed R Crim P Rule 2. In the United States, environmental law is probably at its weakest as a means of ensuring predictable, efficient justice in the context of the pre-enforcement judicial review of administrative orders issued by EPA that require private parties to respond to some pollution problem, although this weakness varies depending on the statute under which the order was issued and the way in which the courts have interpreted that statute. Compare e.g. Comprehensive Environmental Response, Compensation and Liability Act of $1980 \mathrm{~s} 113(\mathrm{~h})$, 42 USC s 9613(h) (2012), with Sackett v EPA, 132 S Ct 1367 (2012). See PEERENBOOM (n 12) 285 .

96 See Donald C CLARKE, 'Power and Politics in the Chinese Court System: The Enforcement of Civil Judgments' (1996) 10 Colum J Asian L 1, 27-34.

97 See PEERENBOOM (n 12) $315^{-16}$.

98 Confidential interview with a Guangdong legal scholar (August 26, 2016).

99 See PEERENBOOM (n 12) 315-16.

$100 \quad$ See e.g. ibid. 311.

101 See generally ibid. $280-35^{2}$. 
laws in the eyes of regulated parties, and for that reason do nothing to encourage voluntary compliance.

\subsection{Law as a Means of Protecting Human Rights}

The fifth goal of the rule of law is the protection of human rights from infringement by the State. ${ }^{102}$ The strength of the law in protecting human rights per se is much less important for the effectiveness of the Western-style features of any society's environmental laws, however, than it is for the evidence that it provides for the existence of a rights-based legal tradition in that society. The existence of a rights-based legal tradition makes it much more likely that the State will be bound by law as a practical matter because it legitimizes the efforts of citizens to ensure such a result as a matter of right.

The two great Western legal traditions are both rights-based. One of the most fundamental concepts in the civil law tradition is that of the 'subjective right,' which refers to the power of a person to act in his or her own interests in the context of a given private legal relation with another person, including with respect to a thing, such as property. ${ }^{103}$ In the common law tradition, private legal relations are conceptualized largely in terms of the parties' rights, which are implied by certain facts supposed to be true of a given party, and which complement the legal burdens that the law imposes on the other party or parties because of facts supposed to be true of them. ${ }^{104}$ In public law, the Western conception of the State as arising from a contract among individuals who are ontologically prior to it-especially as expounded by the seventeenth-century British philosopher John Locke ${ }^{105}$ - posits the notion that the contract recognizes that individuals retain certain negative rights as against the State (otherwise known as 'civil liberties'), which those individuals enjoyed as natural liberties before the contract was formed. ${ }^{106}$ American culture places an especially high value on the concept of individual rights in both the private and the public spheres, as de Tocqueville observed more than 175 years ago. ${ }^{107}$

Probably the most important manifestation of this phenomenon in the context of us environmental law is the widespread use by both civil society organizations and industrial enterprises of the citizen suit provisions

\footnotetext{
102 Cf. BELTON (n 12) 14-15.

103 See MERRYMAN \& PÉREZ-PERDOMO (n 17) 70, 72-75.

104 See Oliver Wendell HOLMES, The Common Law (original work 1881, Mark DeWolfe HOWE ed, Belknap Press 1963) 169-70, 173, 188, 227, 265.

105 See generally John LOCKE, Second Treatise of Government (original work 1764, 6th edn, C B MACPHERSON ed, Hackett Publishing 1980).

106 See e.g. ibid. ss 95, 128-31.

107 See DE TOCQUEVILLE I (n 31) 254.
} 
embedded in nearly all federal environmental statutes to enforce the requirements of those statutes against the State. ${ }^{108}$ In the absence of a citizen suit provision, the federal Administrative Procedure Act ('APA') ${ }^{109}$ entitles any person 'aggrieved' by the action of a federal agency, such as the promulgation of an administrative rule, to judicial review. ${ }^{110}$ Citizen suits brought under either the APA or the environmental statutes themselves have played a major role in shaping Us environmental law and policy since the 1970s. ${ }^{111}$

Unlike Western legal traditions, but consistently with its Confucian roots, the Chinese legal tradition is not rights-based, and never has been.12 The imperial $f a$ (法) concerned itself only with the violation of duties, but not with the vindication of rights, consistently with the Confucian essence of China's legal tradition. ${ }^{113}$ Similarly, every constitution or similar document adopted in China between the abdication of the last Qing Emperor and the founding of the PRC treated rights as conditional, as did the constitutional principles promulgated in the twilight of the Empire itself. ${ }^{114}$ China's current Constitution places almost as much emphasis on civil duties as it does on civil liberties and civil rights, ${ }^{115}$ which it links to the civil duties. ${ }^{116}$ It also makes clear that the liberties and rights may not be exercised so as to infringe upon the interests 'of society and of the collective' or of the State. ${ }^{117}$

This cultural perspective on legal rights as against the State extends to the implementation of China's environmental laws. For example, China's Administrative Procedure Law ${ }^{118}$ and Administrative Reconsideration Law ${ }^{119}$

108 See e.g. WENNER (n 35) 39-40, 41 tbl 6.

109 Administrative Procedure Act, Pub L 79-404, 6o Stat 237 (1946) (codified as amended at 5 USC ss 551-559, 701-706, 1305, 3105, 3344, 5372, 7521).

110 Administrative Procedure Act, 5 USC s 702 (2012).

111 See e.g. Wenner (n 35) 44-47, 49-55.

112 See LUBMAN (n 44) 18-21.

113 Cf. BODDE \& MORRIS ( $\mathrm{n}$ 72) 4; Jones ( $\mathrm{n}$ 73) 11; R P PEERENBOOM, 'What's Wrong with Chinese Rights? Toward a Theory of Rights with Chinese Characteristics' (1993) 6 Harv Hum Rts J 29, 43-45.

114 See LUBMAN (n 44) 18.

115 See PRC CONST (n 8) arts 33-50 (1982); ibid. amend IV s 8 (2004).

116 See ibid. arts $33,42,46,49$ (1982). Cf. ibid. arts $52-56$.

117 See ibid. art 51 (1982).

118 Administrative Procedure Law of the People's Republic of China (adopted by the Nat'l People's Cong, April 4, 1989, promulgated by Order No 16 of the President PRC, April 4, 1989, effective Oct. 1, 1990), translated in Asian Legal Information Institute (Laws of the People's Republic of China) <www.asianlii.org/cn/legis/cen/laws/apl279/> (China) (hereinafter PRC Admin Proc Law).

119 Administrative Reconsideration Law of the People's Republic of China (adopted by the Standing Comm Nat'l People's Cong, April 29, 1999, promulgated by Order No 16 of the 
give any citizen, legal person, or other organization the right to administrative reconsideration and judicial review of specific administrative acts alleged to have infringed upon the lawful rights and interests of the complainantincluding acts undertaken pursuant to China's environmental laws-and for administrative review of the legality of certain administrative provisions on which those acts were based. ${ }^{120}$ They do not give anyone the right to judicial review of the legality of administrative rules, regulations, decisions, or orders of general applicability, however, or of specific administrative acts that are final by law. ${ }^{121}$ Thus, they do not give citizens any right to challenge the legality of the laws themselves, which as a practical manner means that the State is bound incompletely by the law in environmental contexts. This shortcoming is sure to undermine the effectiveness of the Western-style features of China's environmental laws because it reduces the likelihood that the administrative authorities will comply with those laws by implementing them as the legislative authorities intended.

\section{Alternative Goals for the Role of Law in China's Quest to Build an Ecological Civilization}

One option for resolving the tension between the heavily law-based strategy for mitigating the negative environmental impacts of industrialization that China has adopted in recent decades, on the one hand, and essential elements of the Chinese legal tradition, on the other hand, would be to Westernize China's legal culture as a prerequisite for the development of a strong rule of law. ${ }^{122}$ Unfortunately, legal traditions—like all cultural phenomena—are inherently

President PRC, April 29, 1999, effective Oct 1, 1999), translated in Asian Legal Information Institute (Laws of the People's Republic of China) <http://www.asianlii.org/cn/legis/cen/ laws $/ \operatorname{arl} 337 />$ (China) (hereinafter PRC Admin Reconsideration Law).

120 See PRC Admin Proc Law (n 118) arts 2-3, 11, 54; PRC Admin Reconsideration Law (n 119) arts $5^{-7}, 28$. China's Law on the Prevention and Control of Water Pollution includes a similar provision applicable to administrative penalties imposed under that statute. See PRC Water Pollution Law (n 5 ) art 84.

121 See PRC Admin Proc Law (n 118) arts 12(2), (4); PRC Admin Reconsideration Law (n 119) art 5 .

122 Cf. Andrew JACOBS \& Chris BUCKLEY, 'China Moves to Reinforce Rule of Law, with Caveats' The New York Times (New York, 23 October 2014) < www.nytimes.com/2014/10/24/ world/asia/china-moves-to-enact-rule-of-law-with-caveats.html $>$ accessed 24 October 2014. 
enduring. ${ }^{123}$ They resist change because human beings both defend their cultural assumptions ${ }^{124}$ and socialize the next generation to those assumptions as constitutive elements of their social group's identity. ${ }^{125}$ If environmental law is to be a more useful ally in China's quest to build an ecological civilization, then China must seek to resolve the cultural tension at the heart of the problem by other means. The most viable alternative would be to establish new goals for the role of environmental law that flow naturally from China's own legal tradition, whether or not those goals are consistent with a strong, Western-style rule of law, and to revise China's environmental laws accordingly. There are at least four such goals.

\subsection{Law as a Supplement to Political Practice}

In accordance with the Chinese legal tradition, law is and always has been merely an instrument of state policy in China, not a transcendent force that binds even the State, and almost never has played more than a subordinate role in maintaining social order. Thus, the role of law in China is and always has been very different from the role of law in Western societies with a strong rule of law, such as the United States. Given this difference, no one should expect law to play as central a role in China's quest to build an ecological civilization as it does in the efforts of Western countries to meet their own environmental challenges. Yet the deluge of environmental statutes, regulations, and other legal measures with prominent Western-style features that have flowed from law-making authorities at all levels of the Chinese State since 1979 make clear that China has been pursuing just such a strategy.

Fortunately, China's own legal tradition suggests a viable alternative. As the American political scientist David Easton has pointed out, law is merely one means of expressing public policies. ${ }^{126}$ Political practice is another. ${ }^{127}$ China's five-year plans, which are ratified by the National People's Congress but are essentially political documents, have demonstrated their effectiveness in achieving ambitious public policy goals with environmental implications. ${ }^{128}$ An even

\footnotetext{
123 Cf. GERRING \& BARRESI (n 18) 252.

124 See Samuel H BARNES, Politics and Culture (University of Michigan Institute for Social Research, Center for Political Studies 1988) 16.

125 Cf. GERRING \& BARRESI (n 18) 249, 255.

126 David EASTON, The Political System: An Inquiry into the State of Political Science (Alfred A Knopf 1953) 130-31.

127 See ibid. 131.

128 See Michael STANDAERT, 'Energy: Chinese Provinces Restrict Electricity Use, Raise Rates to Meet Energy Intensity Goals' (2010) 33 Int'l Env't Rep 941.
} 
greater and more explicit reliance on these plans as the centrepiece of China's efforts to build an ecological civilization — not merely to establish general environmental quality goals, but to prescribe the means of achieving those goalsprobably would be more effective than the current approach, which relies much more heavily on law than the Chinese legal tradition seems to be able to support culturally. Some laws, such as the Law on Evaluation of Environmental Effects, which requires environmental impact assessments for certain types of plans and construction projects, ${ }^{129}$ might have a special role to play in China's quest to build an ecological civilization because of their prospective effects. The policy goals expressed through many, if not most, of China's current environmental laws, however, probably could be achieved more effectively by political rather than by legal means.

\subsection{Law as a Means of Directing the Activities of State Bureaucrats}

For most of China's 2200-year history as a unified polity, Chinese law has focused primarily on policing the activities of state bureaucrats. ${ }^{130}$ This focus is consistent with the Chinese legal tradition, which almost never has assigned law more than a subordinate role in maintaining social order, and never has assigned it a role in constraining the policies of the State. The imperial $f a$ (法), for example, was aimed primarily at the imperial bureaucracy, prescribing both the duties of its members and the punishments that were to be meted out to them when those duties were not fulfilled. ${ }^{131}$ The law concerned itself with relations among private individuals only insofar as they impinged upon the interests of the State. ${ }^{132}$ Even today, many Chinese laws are internal or otherwise not accessible to the public because they are aimed at the bureaucracy. ${ }^{133}$ Although there is much more law in the PRC now than there was in imperial China, including law that applies to private relations among citizens, much of it is the result of China's efforts to integrate its economy with the global economy. ${ }^{134}$ In accordance with the Chinese legal tradition, China's laws remain less concerned with purely private matters than do laws in the West.

On the surface, China's environmental laws appear to follow this traditional pattern. With few exceptions, their provisions are aimed either at prescribing

\footnotetext{
129 See PRC Environmental Effects Evaluation Law (n 5$)$ art 2.

130 See JONES (n 73) 6-7, 9, 11.

131 See ibid.

132 Ibid. 6.

133 See HEAD \& WANG (n 21) 237 (quoting an e-mail message from R Randle EDWARDS to JW HEAD (10 April 2003)).

134 See CHOW (n 57) 59-61.
} 
the behaviour of state bureaucrats or at regulating the activities of private parties or their quasi-private analogues, such as state-owned enterprises, insofar as they impinge on the State's interest in maintaining or achieving a given level of environmental quality. ${ }^{135}$ Lurking beneath this superficially traditional pattern, however, is a host of Western-style policy design principles and policy implementation strategies. The effect of the latter is to entangle private parties and their quasi-private analogues in a thicket of Western-style substantive and procedural legal requirements. In the West, where indigenous legal traditions imply the cultural dimensions of a strong rule of law, private parties generally view requirements like these as merely one of the many legal costs of doing business in a modern society. ${ }^{136}$ In the context of the Chinese legal tradition, however, this legal labyrinth is more likely to be perceived as a culturally alien nuisance, and thus to invite both non-compliance on the part of the private and quasi-private parties to which its requirements apply and a lack of enforcement on the part of the authorities charged with doing so. ${ }^{137}$ China's environmental laws probably would be stronger allies in its quest to build an ecological civilization if they were aimed much more than they are now at policing the activities of state bureaucrats, such that - to the maximum extent possible given the State's policy goals - those laws would apply to private parties and their quasi-private analogues only indirectly through those bureaucrats. For example, instead of seeking to achieve their goals primarily through the enforcement of performance standards against polluting facilities, China's air and water pollution prevention and control statutes could seek to achieve those goals primarily by enforcing against the relevant state bureaucrats the ambient air and water quality standards from which the performance

135 See e.g. PRC Noise Pollution Law (n 5 ) arts 12, 45; PRC Marine Environmental Protection Law (n 5 ) arts 6, 55; PRC Atmospheric Pollution Law (n 5) arts 18, 38; PRC Environmental Effects Evaluation Law (n 5 ) arts 7, 22; PRC Solid Wastes Law (n 5 ) arts 17, 27; PRC Water Pollution Law (n 5) arts 22, 40; PRC Amended Environmental Protection Law (n 4) arts $14,42$.

136 Cf. Jesse H AUSUBEL, David G VICTOR \& Iddo K WERNIK, 'The Environment Since 1970' (1995) 2 (Autumn) Consequences.

137 Cf. Carlos Wing-hung LO, Gerald E FRYXELL \& Wilson Wai-ho WONG, 'Effective Regulations with Little Effect? The Antecedents of the Perceptions of Environmental Officials on Enforcement Effectiveness in China' (2006) 38 Environmental Management 388, 390, 391; Xuehua ZHANG, 'Enforcing Environmental Regulations in Hubei Province, China: Agencies, Courts, Citizens' (PhD dissertation, Stanford University 2008) 29-31, $53-56<$ http://proquest.umi.com/pqdweb?did=1611039441\&sid=1\&Fmt=2\&clientId=7935 $6 \& \mathrm{RQT}=309 \& \mathrm{VName}=\mathrm{PQD}>$. 
standards largely are derived, ${ }^{138}$ leaving those bureaucrats free to fulfil their statutory obligations by any otherwise permissible means.

\subsection{Law as a Means of Identifying the Proper Punishments for Violations of Legal Duties}

In accordance with the emphasis of the Chinese legal tradition on the violation of duties rather than the vindication of rights, punishment always has played a special role in Chinese law. ${ }^{139}$ One Western scholar has likened the Great Qing Code, for example, to a huge grid of fact patterns intended to enable the magistrate to identify the proper punishment for any legally significant act, ${ }^{140}$ which essentially meant the failure to fulfil any legally significant duty.

In general, China's environmental laws are consistent with this traditional emphasis on punishment. They include, for example, special provisions prescribing administrative punishments for state bureaucrats who abuse their authority or are derelict in their duty, even when their behaviour is not criminal, fraudulent, or for personal gain. ${ }^{141}$ These provisions do not merely require the setting aside of an unlawful act committed or the compulsion of a lawful act unreasonably delayed or unlawfully withheld, as one would expect in a society with a rights-based legal tradition. ${ }^{142}$ Similarly, China's Administrative Punishments Law ${ }^{143}$ imposes administrative punishments for a wide variety of purely administrative wrongs, including the failure to punish the unlawful acts of others. ${ }^{144}$

138 Cf. PRC Air Pollution Law ( $\mathrm{n}_{5}$ ) art 6, art 7, paras 1-2, art 13, art 48; PRC Water Pollution Law (n 5) arts 11-12, 13, paras 1-2, art 20, para 2, art 74 .

139 See HEAD \& WANG (n 21) 219-20; 'Reducing Death Penalty Crimes in China More Symbol than Substance' [2010] (Fall) Dialogue 1, $1<$ http://duihua.org/work/publications/ nl/nl_pdf/nl_41.pdf> accessed 24January 2012.

140 JONES (n 73) 12.

141 See PRC Noise Pollution Law (n 5) art 62; PRC Marine Environmental Protection Law (n 5) art 94; PRC Atmospheric Pollution Law (n 5) art 65; PRC Environmental Effects Evaluation Law (n 5 ) arts 28, 30, 32, 35; PRC Solid Wastes Law (n 5) art 67; PRC Amended Environmental Protection Law (n 4) art 68. The Law on the Prevention and Control of Water Pollution includes a similar provision that refers merely to punishments prescribed by law. See PRC Water Pollution Law (n 5 ) art 69.

142 Cf. e.g. Administrative Procedure Act, 5 UsC s 706 (2012).

143 Administrative Punishments Law (adopted by the Nat'l People's Cong, March 17, 1996, promulgated by Order No 63 of the President PRC, March 17, 1996, effective Oct 1, 1996), translated in Asian Legal Information Institute (Laws of the People's Republic of China) $<$ www.asianlii.org/cn/legis/cen/laws/apl330/> (China).

144 See ibid. arts $55^{-58}, 61-62$. 
One type of punishment is conspicuously absent from China's environmental law regime, however. Neither China's environmental statutes nor its Administrative Punishments Law provide for the punishment of government officials-such as those in local people's governments-who impede the implementation or enforcement of environmental laws by other government officials-such as the officials in local ЕРBs, ${ }^{145}$ which has been the principal institutional impediment to the effectiveness of China's environmental laws. By addressing this problem specifically, whether or not other Chinese laws do so in general terms, China's environmental laws could be stronger allies in its quest to build an ecological civilization, and in a way that is consistent with the Chinese legal tradition.

\subsection{Law as a Means of Accommodating or Reinforcing Widely Shared Social Norms}

In accordance with the Chinese legal tradition, China's laws always have been applied in ways that reflect prevailing social norms. ${ }^{146}$ Notwithstanding Deng Xiaoping's emphasis on equality before the law as a principal goal of his postMao legal reforms, ${ }^{147}$ most Chinese people continue to believe that laws should be applied in ways that reflect extra-legal factors such as the relationship and circumstances of the parties and widely shared conceptions of justice.

This enduring cultural preference in China for flexible legal norms that vary in accordance with socially derived, extra-legal factors could be harnessed in a way that would make China's environmental laws stronger allies in its quest to build an ecological civilization. One of the most basic institutional obstacles to the effectiveness of environmental laws in China has been the combination of state structural factors and political incentives that strongly encourage officials in local governments to resolve the conflict perceived to exist between short-term economic development goals and longer term environmental quality goals in favour of the former by helping regulated parties to evade the requirements of the law. One strategy for mitigating this institutional weakness would be to make those laws more pervasively but precisely flexible in ways

145 In the context of provisions that impose administrative punishments on administrative personnel who have imposed administrative punishments in cases that should have been transferred by law to the judiciary for criminal prosecution, however, the Administrative Punishments Law provides for the criminal punishment of anyone who 'play[s] favouritism and protect[s] illegal acts.' Ibid. art 61.

146 See BODDE \& MORRIS (n 72) 29, 30, 33-38, 43; JONES (n 73) 16-17; LENG (n 54 ) 363-65; LO, 'Socialist Legal Theory' (n 52) 473, 473-74 $\mathrm{n} 14$.

147 Cf. e.g. DENG Xiaoping, 'On Reform' (n 58) 309, 315-16. 
that would accommodate or would reinforce certain economically relevant social relationships valued widely at the local level.

For example, in accordance with provisions of the Environmental Protection Law, ${ }^{148}$ China's air and water pollution prevention and control statutes currently authorize certain local governments to establish local performance standards for sources of air and water pollution that are supplementary to or more stringent than-but not less stringent than-national standards. ${ }^{149}$ To the extent that performance standards would remain a key feature of those laws, ${ }^{150}$ one strategy for encouraging voluntary compliance with those standards by enhancing their perceived legitimacy at the local level would be to amend the laws to permit local authorities to impose less stringent standards on industrial enterprises that contribute disproportionately to local economic development, especially by providing a large percentage of the local population with decent jobs at decent wages, while imposing more stringent standards on other enterprises, such as those that employ mostly migrant workers from elsewhere in China, ${ }^{151}$ as long as the applicable ambient environmental quality standards are met. At first glance, this approach might not seem to be a prescription for better environmental quality. Yet its most essential features would be analogous to those of the cap-and-trade approach to curbing acidrain-related air pollution that first emerged in the United States in 1990, and which was so successful that other free market jurisdictions have adopted it as a strategy for reducing GHG emissions. ${ }^{152}$ Both approaches permit similar sources to emit pollutants in different amounts, but within a legal constraint on the combined emissions from all sources. In a cap-and-trade system, that constraint is imposed explicitly by a legal cap on aggregate emissions. In the Chinese analogue, it would be imposed implicitly by the legal requirement

148 Cf. PRC Amended Environmental Protection Law (n 4) art 16.

149 See PRC Atmospheric Pollution Law (n 5 ) art 7, paras 1-2; PRC Water Pollution Law (n 5 ) art 13, paras 1-2.

150 Cf. (n 140) and accompanying text.

151 Cf. Andrew JACOBS, 'Chinese Factories Now Compete to Woo Laborers' The New York Times (New York, 12 July 2010) < www.nytimes.com/2010/07/13/world/asia/13factory.html> accessed 22 September 2012.

152 See e.g. Richard CONNIFF, 'The Political History of Cap and Trade' Smithsonian Magazine (Washington, DC, August 2009) < www.smithsonianmag.com/air/the-political-history-ofcap-and-trade-34711212/> accessed December 22, 2016. Although China is poised to implement the world's biggest cap-and-trade program in 2017, it remains to be seen whether such a market-based system will work in a country that lacks a strong tradition of free markets. See Bloomberg News, 'Emissions Trading: China Turns to Free Markets to Tame Fossil Fuel Pollution' (2016) 39 Int'l Env't Rep 1143. 
for achieving a particular level of ambient environmental quality in the relevant jurisdiction.

\section{Back to the Future, or Forward to the Past}

For most of its 2200-year history as a unified polity, China has looked to its own past for the wisdom to propel itself into the future. ${ }^{153}$ Only since the late nineteenth century has China been inclined to turn its gaze westward for inspiration, including to the West's environmental laws, ${ }^{154}$ with a mixed record of success in adapting Western models to Chinese circumstances. ${ }^{155}$ Westernstyle industrialization has produced enormous economic benefits for China, but at a cost in environmental quality and related impacts on human quality of life that have become so high as to threaten to overwhelm those economic gains. Since its inception, key proponents of the ecological civilization concept have recognized the value of China's ancient heritage in the quest to resolve China's environmental crisis. ${ }^{156}$ If properly harnessed, China's venerable legal tradition could be a strong ally in that quest. It is hard to say exactly what an environmental law regime designed to adhere closely to the essential elements of China's own legal tradition would look like, although the foregoing suggestions for change could offer some clues. It is safe to say, however, that any such regime would look very different from the Western environmental law regimes to which China has looked for inspiration in recent decades, and therefore probably would look very different from the PRC's current environmental law regime.

153 See e.g. CONFUCIUS, The Analects (D C LAU trs, 2nd edn, Chinese UP 1992) bk viI, para 1; Sun Yat-sen, San Min Chu I: The Three Principles of the People with Two Supplementary Chapters by Chiang Kai-shek (Frank W PRICE trs, Commission for the Compilation of the History of the Kuomintang ed, nd) 37-41, 151, 184; Chiang Kai-shek, 'Conclusion to Two Supplementary Chapters to Lectures on the Principle of People's Livelihood' in ibid. 318, 324-29.

154 See Michael STANDAERT, 'China: Country to Try Out Updated Version of Environmental Law in Shanxi Province' (2011) 34 Int'l Env't Rep 708.

155 See Percy Horace KENT, The Passing of the Manchus (original work 1912, photo reprint edn, University Publications of America 1977) 12-13, 26-29, 34, 65, 168-69, 36o, 374-75; Paul S REINSCH, An American Diplomat in China (Doubleday, Page 1922) 42, 231; SHARMAN (n 46) 218-19; SUN Yat-sen (n 155) 46, 108-09, 136; CH'ÊN (n 45) 145, 245; FAIRBANK, REISCHAUER \& CRAIG (n 46) 315-20; PEERENBOOM (n 12) 43, 208; Keller (n 51) 712.

${ }_{15} 6$ See Opinions on Ecological Civilization (n 26) virI(xxix); YE Qianji (n 30); Pan Yue, 'Evolution of an Ecological Civilization' (n 30); PAN Yue, 'Looking Forward' (n 30$)$. 
The preparation of an earlier version of this manuscript was supported in part by a 2014 summer research grant from Southern New Hampshire University. The author thanks Professor Wang Lianyong, College of Economics and Management, Southwest University, for his summary of Professor Ye Qianji's early development of the ecological civilization (shengtai wenming 生态文明) concept, and for the translation of the key pages from Professor Ye's seminal book on eco-farming. 